\title{
Evaluation of Erythrocyte Morphometric Indices in Juvenile Red Spotted Grouper, Epinephelus akaara under Elevated Water Temperature
}

\author{
Md Mofizur Rahman ${ }^{1,2}$ and ${ }^{\dagger}$ Hea Ja Baek ${ }^{1}$ \\ ${ }^{1}$ Dept. of Marine Biology, Pukyong National University, Busan 48513, Korea \\ ${ }^{2}$ Dept. of Fisheries and Marine Science, Noakhali Science and Technology University, Noakhali 3814, Bangladesh
}

\begin{abstract}
Higher thermal exposure can influence the blood cell morphology and count. Hence, based on the previous results (Rahman et al., 2019), the present study evaluated the morphometric indices of erythrocytes and their nucleus under different water temperatures $\left(25^{\circ} \mathrm{C}, 28^{\circ} \mathrm{C}, 31^{\circ} \mathrm{C}\right.$, and $\left.34^{\circ} \mathrm{C}\right)$ to investigate their use as an indicator of thermal stress in red spotted grouper, Epinephelus akaara. 180 healthy specimens of E. akaara were exposed to four temperature conditions $\left(25^{\circ} \mathrm{C}\right.$ as control, $28^{\circ} \mathrm{C}, 31^{\circ} \mathrm{C}$, and $34^{\circ} \mathrm{C}$ ) for 42 days, following 2 weeks of acclimation at $25^{\circ} \mathrm{C}$. Erythrocyte major axis (EL), erythrocyte minor axis (EW), nucleus major axis (NL), and nucleus minor axis (NW) were examined from the blood smears on each sampling day (i.e., 2, 7, and 42 days of thermal exposure). EL and NL were significantly decreased, whereas EW and NW were increased at higher water temperature $\left(31^{\circ} \mathrm{C}\right.$ and $\left.34^{\circ} \mathrm{C}\right)$. The major-minor axis proportions of erythrocytes and their nucleus $(\mathrm{EL} / \mathrm{EW} ; \mathrm{NL} / \mathrm{NW})$ were decreased with increasing water temperature $\left(31^{\circ} \mathrm{C}\right.$ and $\left.34^{\circ} \mathrm{C}\right)$. The strong relationships were observed among the morphometric indices of erythrocytes and their nucleus, especially in EL vs. NL and EW vs. NW. This study reveals that elevated water temperature $\left(31^{\circ} \mathrm{C}\right.$ and $\left.34^{\circ} \mathrm{C}\right)$ can influence the major and minor axis morphometry of erythrocytes and their nucleus in red spotted grouper. These indices may be used as stress indicators to monitor the health status of E. akaara and probably for other fish species.
\end{abstract}

Key words : Epinephelus akaara, Temperature, Erythrocyte, Morphometric indices, Stress indicator

\section{INTRODUCTION}

Analysis of blood cell can reveal a measurable amount of physiological changes in fish more rapidly than any physiological assessment parameters (Rowan, 2007). It can also respond to changes in other tissues due to exposure of environmental stressors (i.e., temperature, salinity, overcrowding, and water quality) (Ruas et al., 2008). Therefore, examining blood cells has been considered a valuable approach for analyzing the health status of fish and enhancing our understanding of the relationship of blood characteristics with the habitat and adaptability of a species to an environment (Fazio et al., 2012; Shahjahan et al., 2018; De et al., 2019; Islam et al., 2019). Thus, the use of blood indicators in fisheries research is growing rapidly as it is very important in toxicological research, environmental monitoring and predicting of fish health conditions (Barcello s et al., 2004).

Unlike human and most mammals, fish possess an ovalshaped structure of erythrocyte with a condensed nucleus (Jagoe \& Welter, 1995). Fish erythrocytes are more responsive to environmental stresses, and often vary in

\footnotetext{
Manuscript received September 30, 2019, Received in revised form October 12, 2019, Accepted October 23, 2019

${ }^{\dagger}$ Corresponding Author : Hea Ja Baek, Dept. of Marine Biology, Pukyong National University, Busan 48513, Korea. Tel: +82-51-629-5924, E-mail: hjbaek@pknu.ac.kr

This is an Open Access article distributed under the terms of the Creative Commons Attribution Non-Commercial License (http:// creative-commons.org/licenses/by-nc/3.0) which permits unrestricted non-commercial use, distribution, and reproduction in any medium, provided the original work is properly cited.
} 
morphology and effectiveness of oxygen transport (LoweJinde \& Niimi, 1983). However, variations in erythrocytes and its nuclear size and structure within species are smaller compared to interspecies differences (Najiah et al., 2008; Fang et al., 2014). In our previous study, we examined the blood cell morphology and number of E. akaara under high water temperature exposure and the findings are useful to assess the primary immune response of fish under stressful conditions (i.e., thermal stress) (Rahman et al., 2019).

The red spotted grouper is a sub-tropical species of serranidae family which prefers to inhabit shallower depths of the coastal area (Sadovy \& Cornish, 2000). It is a promising aquaculture species due to its high market value in southern Japan, Korea, Hong Kong, Taiwan, and southern China (Morris et al., 2000). The normal range of water temperature in the tropics to which fish are adapted is $25^{\circ} \mathrm{C}-35^{\circ} \mathrm{C}$ (Howerton, 2001). The optimal water temperature at which E. akaara can live without stress was reported to be $24^{\circ} \mathrm{C}-28^{\circ} \mathrm{C}$ (Cho et al., 2015; Lee \& Baek, 2018). However, temperature can increase to a point that may become harmful for growth and damage physiological processes (Fu et al., 2018). Though a number of studies were conducted to make a better understanding of blood cell morphology of fishes under various environmental toxicants (Rowan, 2007; Osman et al., 2018; Shahjahan et al., 2018; Islam et al., 2019; Rahman et al., 2019), the effect of high temperature on erythrocyte and nuclear morphometry are not well studied. Therefore, the present study was intended to evaluate the morphometric indices of erythrocytes and their nucleus under elevated water temperature which will help to check the health status of E. akaara in a quick time.

\section{MATERIALS AND METHODS}

\section{Experimental fishes and design}

180 healthy and active specimens of E. akaara with an average total length (TL) of $8.28 \pm 0.10 \mathrm{~cm}$ and body weight $(\mathrm{BW})$ of $8.53 \pm 0.27 \mathrm{~g}$ were collected from the Marine
Science Institute, Jeju National University, Korea. The juveniles were acclimated in aquaria at a water temperature of $25 \pm 0.5^{\circ} \mathrm{C}$, salinity of $34 \mathrm{psu}$, dissolved oxygen levels $\geq 6.6$ $\mathrm{mg} / \mathrm{L}, \mathrm{pH}$ of 7.8 , and a 12L: 12D photoperiod for 2 weeks before the experiment. The fish were fed commercial feed (Otohime Hirame; Marubeni Nisshin Feed Co., Ltd., Tokyo, Japan) twice a day until satiation. The fishes were exposed to four temperature conditions $\left(25^{\circ} \mathrm{C}\right.$ as control, $28^{\circ} \mathrm{C}, 31^{\circ} \mathrm{C}$, and $34^{\circ} \mathrm{C}$ ), each with three replications for 6 weeks. Temperature was gradually increased $\left(\Delta 1^{\circ} \mathrm{C} / \mathrm{h}\right)$ using a thermostat (OKE-6422H; OKE, Busan, Korea) to reach the target temperature conditions $\left(25^{\circ} \mathrm{C}, 28^{\circ} \mathrm{C}, 31^{\circ} \mathrm{C}\right.$, and $34^{\circ} \mathrm{C}$ ). Approximately $10 \%$ of the water was replaced daily with filtered clean seawater as feces and debris were siphoned from the tank.

\section{Sampling and erythrocyte morphometry analysis}

15 fishes were sampled from each temperature group (i.e., 5 fishes from each aquaria; $\mathrm{n}=15$ ) on each sampling day (i.e., 2, 7, and 42 days of thermal exposure). Fish were randomly captured and lightly anaesthetized with $300 \mathrm{ppm}$ 2-phenoxyethanol (Sigma Aldrich, St. Louis, MO, USA). Blood was collected from the caudal vein using heparinized capillary tubes, labeled, and stored in $1.5 \mathrm{~mL}$ centrifuge tubes. The whole blood was withdrawn less than 1 min per fish to avoid handling stress.

Blood smears were prepared immediately after collection, air-dried for $10 \mathrm{~min}$, fixed in $95 \%$ methanol for $5 \mathrm{~min}$, stained with Wright-Giemsa solution, rinsed with distilled water, air-dried and mounted with malinol. Three slides were prepared from each fish and then photos were taken under light microscopy. Erythrocytes in fish are elliptical, and as such, two different diameters are provided: erythrocyte major axis (EL) and erythrocyte minor axis (EW). Nucleus major axis (NL) and nucleus minor axis (NW) were also obtained. On each slide, EL and EW of randomly selected 100 mature erythrocytes and their nuclei (NL and NW) were measured by an Olympus ocular micrometer at a 
magnification of $\times 600$ (Olympus BX-50, Japan). Erythrocyte and nuclear sizes (ES and NS) were calculated according to formulas $[(\mathrm{EL} \times \mathrm{EW} \times \pi) / 4]$ and $[(\mathrm{NL} \times \mathrm{NW} \times \pi) / 4]$, respectively (Metin et al., 2008).

\section{Statistical analysis}

Data have been presented as mean \pm SEM and analyzed by using SPSS statistics software (ver. 21.0; IBM Corp., Armonk, NY, USA). One-way analysis of variance (ANOVA) followed by Duncan's multiple range test was used to assess the significant differences among the different temperature groups. Pearson's correlation coefficient test was conducted to estimate the relationships among the morphometric indices of erythrocyte. In addition, regression analysis and goodness of fit $\left(\mathrm{R}^{2}\right)$ were determined when there was a significant correlation between tested variables. The results were considered significant at $p<0.05$.

\section{RESULTS AND DISCUSSION}

Elevated water temperature induced significant changes in erythrocytes and nucleus structure of $31^{\circ} \mathrm{C}$ and $34^{\circ} \mathrm{C}$ groups, compared to those in the $25^{\circ} \mathrm{C}$ and $28^{\circ} \mathrm{C}$ groups. Fishes of $31^{\circ} \mathrm{C}$ and $34^{\circ} \mathrm{C}$ groups showed round-shaped erythrocyte structure containing large nucleus, whereas erythrocytes of $25^{\circ} \mathrm{C}$ and $28^{\circ} \mathrm{C}$ groups showed oval-shaped structure with condensed nucleus (Fig. 1).

The morphometric indices of erythrocytes and their nucleus under different water temperatures $\left(25^{\circ} \mathrm{C}, 28^{\circ} \mathrm{C}\right.$, $31^{\circ} \mathrm{C}$, and $34^{\circ} \mathrm{C}$ ) are shown in Table 1 . Major and minor axis morphometry, and size of erythrocytes and nucleus differed significantly during the thermal exposure period (42 days). The major and minor axis of erythrocytes and nucleus were changed reversely. EL and NL were significantly $(p<0.05)$ decreased, whereas EW and NW were increased at higher water temperature $\left(31^{\circ} \mathrm{C}\right.$ and $34^{\circ} \mathrm{C}$ ). In addition, the major-minor axis proportion of erythrocytes and their nucleus (EL/EW; NL/NW) were
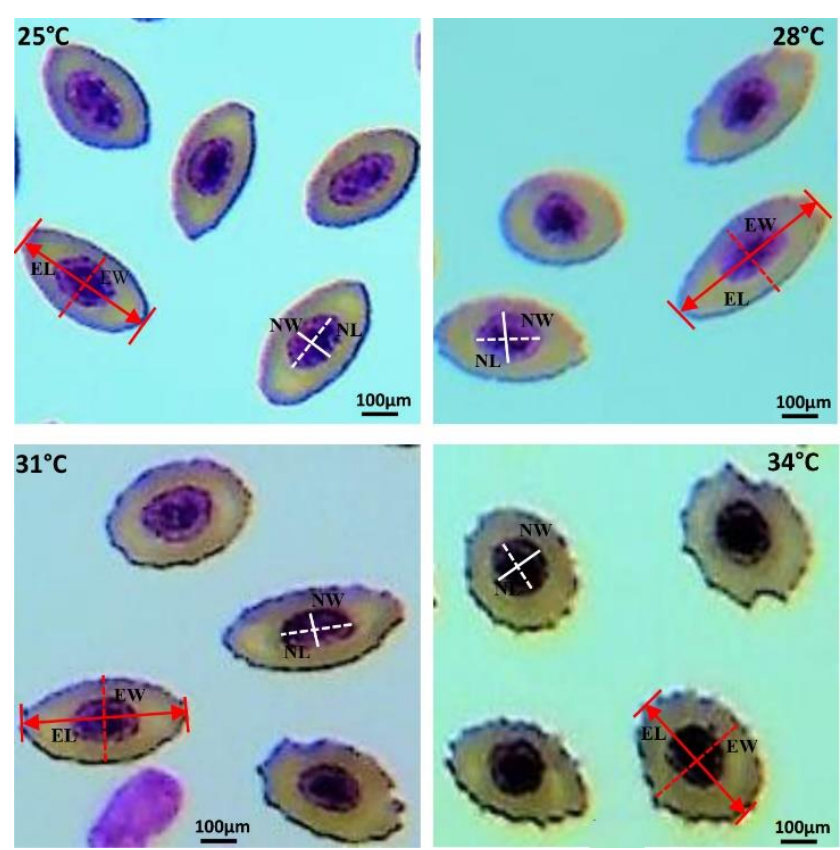

Fig. 1. Measurement of major and minor axis of erythrocyte and nucleus of red spotted grouper, Epinephelus akaraa. Red and white line indicates the diameters of erythrocytes and nucleus, respectively. EL, erythrocyte major axis; EW, erythrocyte minor axis; NL, nucleus major axis; NW, nucleus minor axis. Scale bars $=100 \mu \mathrm{m}$.

decreased with increasing water temperature $\left(31^{\circ} \mathrm{C}\right.$ and $34^{\circ} \mathrm{C}$ ). On the other hand, the size of erythrocytes and their nucleus (ES, NS and ES/NS) showed irregular changes under elevated water temperature.

Both positive and negative correlations were observed among the morphometric indices of erythrocytes and nucleus of red spotted grouper (Table 2 and Fig. 2a-f). A highly significant positive relationship was found in EL vs. NL and EW vs. NW, whereas significant negative relationship was detected in EL vs. EW, NL vs. NW, EL vs. NW, and EW vs. NL.

Since erythrocytes are influenced by a variety of environmental stressors, they have the potential to be used as stress indicators. Their evaluation in fish has become an important means of understanding the toxicological impacts of exposure hazards (Borges et al., 2007). In this study, morphometric indices of erythrocytes and their nucleus 
Table 1. Changes in morphometric indices of erythrocytes and nucleus [major and minor axis, and size] in red spotted grouper, Epinephelus akaara exposed to different water temperatures $\left(25^{\circ} \mathrm{C}, 28^{\circ} \mathrm{C}, 31^{\circ} \mathrm{C}\right.$, and $34^{\circ} \mathrm{C}$ ) for 42 days

\begin{tabular}{|c|c|c|c|c|}
\hline \multirow{2}{*}{ Morphometric indices } & \multirow{2}{*}{$\begin{array}{l}\text { Temperature } \\
\text { groups }\end{array}$} & \multicolumn{3}{|c|}{ Period of thermal exposure (days) } \\
\hline & & 2 & 7 & 42 \\
\hline \multirow{4}{*}{$\mathrm{EL}(\mu \mathrm{m})$} & $25^{\circ} \mathrm{C}$ & $11.53 \pm 0.09^{\mathrm{a}}$ & $11.45 \pm 0.07^{\mathrm{a}}$ & $11.30 \pm 0.08^{\mathrm{a}}$ \\
\hline & $28^{\circ} \mathrm{C}$ & $11.36 \pm 0.02^{\mathrm{a}}$ & $11.19 \pm 0.07^{\mathrm{a}}$ & $10.35 \pm 0.22^{\mathrm{b}}$ \\
\hline & $31^{\circ} \mathrm{C}$ & $9.62 \pm 0.17^{b}$ & $9.02 \pm 0.14^{\mathrm{b}}$ & $8.68 \pm 0.18^{c}$ \\
\hline & $34^{\circ} \mathrm{C}$ & $8.34 \pm 0.04^{\mathrm{c}}$ & $8.44 \pm 0.12^{c}$ & $8.78 \pm 0.19^{c}$ \\
\hline \multirow{4}{*}{$\mathrm{EW}(\mu \mathrm{m})$} & $25^{\circ} \mathrm{C}$ & $5.59 \pm 0.10^{\mathrm{b}}$ & $5.59 \pm 0.08^{\mathrm{c}}$ & $5.77 \pm 0.22^{\mathrm{c}}$ \\
\hline & $28^{\circ} \mathrm{C}$ & $5.42 \pm 0.03^{\mathrm{b}}$ & $5.91 \pm 0.07^{b}$ & $5.68 \pm 0.14^{\mathrm{c}}$ \\
\hline & $31^{\circ} \mathrm{C}$ & $6.01 \pm 0.02^{\mathrm{a}}$ & $6.17 \pm 0.09^{b}$ & $6.49 \pm 0.07^{\mathrm{b}}$ \\
\hline & $34^{\circ} \mathrm{C}$ & $6.03 \pm 0.09^{\mathrm{a}}$ & $7.16 \pm 0.08^{\mathrm{a}}$ & $7.36 \pm 0.11^{\mathrm{a}}$ \\
\hline \multirow{4}{*}{ EL/EW } & $25^{\circ} \mathrm{C}$ & $2.06 \pm 0.05^{\mathrm{a}}$ & $2.05 \pm 0.12^{\mathrm{a}}$ & $1.96 \pm 0.06^{\mathrm{a}}$ \\
\hline & $28^{\circ} \mathrm{C}$ & $2.09 \pm 0.09^{\mathrm{a}}$ & $1.90 \pm 0.08^{\mathrm{a}}$ & $1.82 \pm 0.05^{\mathrm{a}}$ \\
\hline & $31^{\circ} \mathrm{C}$ & $1.60 \pm 0.06^{\mathrm{b}}$ & $1.47 \pm 0.05^{\mathrm{b}}$ & $1.34 \pm 0.04^{\mathrm{b}}$ \\
\hline & $34^{\circ} \mathrm{C}$ & $1.39 \pm 0.02^{\mathrm{c}}$ & $1.18 \pm 0.06^{\mathrm{c}}$ & $1.19 \pm 0.03^{c}$ \\
\hline \multirow{4}{*}{$\mathrm{NL}(\mu \mathrm{m})$} & $25^{\circ} \mathrm{C}$ & $5.12 \pm 0.22^{\mathrm{a}}$ & $5.48 \pm 0.05^{\mathrm{a}}$ & $5.12 \pm 0.06^{b}$ \\
\hline & $28^{\circ} \mathrm{C}$ & $5.06 \pm 0.17^{\mathrm{a}}$ & $5.30 \pm 0.15^{\mathrm{a}}$ & $5.46 \pm 0.06^{\mathrm{a}}$ \\
\hline & $31^{\circ} \mathrm{C}$ & $4.66 \pm 0.21^{\mathrm{a}}$ & $4.15 \pm 0.04^{b}$ & $4.47 \pm 0.06^{\mathrm{c}}$ \\
\hline & $34^{\circ} \mathrm{C}$ & $3.55 \pm 0.14^{\mathrm{b}}$ & $4.21 \pm 0.19^{\mathrm{b}}$ & $4.49 \pm 0.10^{c}$ \\
\hline \multirow{4}{*}{$\mathrm{NW}(\mu \mathrm{m})$} & $25^{\circ} \mathrm{C}$ & $2.94 \pm 0.07^{\mathrm{b}}$ & $3.32 \pm 0.08^{\mathrm{c}}$ & $2.65 \pm 0.06^{\mathrm{c}}$ \\
\hline & $28^{\circ} \mathrm{C}$ & $3.05 \pm 0.10^{b}$ & $3.20 \pm 0.03^{\mathrm{c}}$ & $3.28 \pm 0.12^{b}$ \\
\hline & $31^{\circ} \mathrm{C}$ & $3.51 \pm 0.08^{\mathrm{a}}$ & $3.83 \pm 0.02^{b}$ & $3.68 \pm 0.24^{b}$ \\
\hline & $34^{\circ} \mathrm{C}$ & $3.73 \pm 0.08^{\mathrm{a}}$ & $4.00 \pm 0.03^{\mathrm{a}}$ & $4.28 \pm 0.09^{\mathrm{a}}$ \\
\hline \multirow{4}{*}{ NL/NW } & $25^{\circ} \mathrm{C}$ & $1.74 \pm 0.09^{\mathrm{a}}$ & $1.65 \pm 0.03^{\mathrm{a}}$ & $1.94 \pm 0.07^{\mathrm{a}}$ \\
\hline & $28^{\circ} \mathrm{C}$ & $1.67 \pm 0.02^{\mathrm{a}}$ & $1.66 \pm 0.04^{\mathrm{a}}$ & $1.71 \pm 0.02^{\mathrm{b}}$ \\
\hline & $31^{\circ} \mathrm{C}$ & $1.33 \pm 0.04^{b}$ & $1.09 \pm 0.06^{\mathrm{b}}$ & $1.20 \pm 0.04^{\mathrm{c}}$ \\
\hline & $34^{\circ} \mathrm{C}$ & $0.95 \pm 0.05^{\mathrm{c}}$ & $1.05 \pm 0.04^{b}$ & $1.05 \pm 0.04^{\mathrm{d}}$ \\
\hline
\end{tabular}


Table 1. Continued

\begin{tabular}{|c|c|c|c|c|}
\hline \multirow{2}{*}{ Morphometric indices } & \multirow{2}{*}{$\begin{array}{l}\text { Temperature } \\
\text { groups }\end{array}$} & \multicolumn{3}{|c|}{ Period of thermal exposure (days) } \\
\hline & & 2 & 7 & 42 \\
\hline \multirow{4}{*}{$\mathrm{ES}\left(\mu \mathrm{m}^{2}\right)$} & $25^{\circ} \mathrm{C}$ & $50.65 \pm 0.65^{\mathrm{a}}$ & $50.18 \pm 0.62^{\mathrm{b}}$ & $51.28 \pm 0.88^{\mathrm{a}}$ \\
\hline & $28^{\circ} \mathrm{C}$ & $48.39 \pm 2.46^{\mathrm{b}}$ & $51.98 \pm 0.28^{\mathrm{a}}$ & $46.24 \pm 0.88^{\mathrm{b}}$ \\
\hline & $31^{\circ} \mathrm{C}$ & $45.55 \pm 3.88^{\mathrm{ab}}$ & $43.98 \pm 0.48^{\mathrm{d}}$ & $44.25 \pm 0.53^{\mathrm{b}}$ \\
\hline & $34^{\circ} \mathrm{C}$ & $39.44 \pm 0.50^{\mathrm{b}}$ & $47.44 \pm 0.14^{\mathrm{c}}$ & $50.78 \pm 1.53^{\mathrm{a}}$ \\
\hline \multirow{4}{*}{$\mathrm{NS}\left(\mu \mathrm{m}^{2}\right)$} & $25^{\circ} \mathrm{C}$ & $11.83 \pm 0.54^{\mathrm{a}}$ & $14.27 \pm 0.12^{\mathrm{a}}$ & $10.65 \pm 0.13^{\mathrm{c}}$ \\
\hline & $28^{\circ} \mathrm{C}$ & $12.14 \pm 0.23^{\mathrm{a}}$ & $13.27 \pm 0.04^{\mathrm{b}}$ & $13.83 \pm 0.33^{\mathrm{b}}$ \\
\hline & $31^{\circ} \mathrm{C}$ & $12.95 \pm 0.39^{\mathrm{a}}$ & $12.49 \pm 0.57^{\mathrm{b}}$ & $13.19 \pm 0.26^{\mathrm{b}}$ \\
\hline & $34^{\circ} \mathrm{C}$ & $10.43 \pm 0.12^{\mathrm{b}}$ & $13.22 \pm 0.15^{\mathrm{b}}$ & $15.13 \pm 0.24^{\mathrm{a}}$ \\
\hline \multirow{4}{*}{$\mathrm{ES} / \mathrm{NS}$} & $25^{\circ} \mathrm{C}$ & $4.30 \pm 0.22^{\mathrm{a}}$ & $3.53 \pm 0.09^{\mathrm{b}}$ & $4.82 \pm 0.21^{\mathrm{a}}$ \\
\hline & $28^{\circ} \mathrm{C}$ & $4.02 \pm 0.26^{\mathrm{ab}}$ & $3.91 \pm 0.08^{\mathrm{a}}$ & $3.44 \pm 0.28^{\mathrm{b}}$ \\
\hline & $31^{\circ} \mathrm{C}$ & $3.55 \pm 0.20^{\mathrm{b}}$ & $3.50 \pm 0.04^{b}$ & $3.41 \pm 0.06^{\mathrm{b}}$ \\
\hline & $34^{\circ} \mathrm{C}$ & $3.81 \pm 0.14^{\mathrm{ab}}$ & $3.59 \pm 0.11^{\mathrm{b}}$ & $3.41 \pm 0.21^{b}$ \\
\hline
\end{tabular}

Sampling was done at three different time points (2, 7, and 42 days). Values are mean \pm SEM of three replicates ( $n=15 ; 5$ fish per tank). 100 erythrocytes and their nucleus were measured from each blood smeared slide.

Different lowercase letters indicate the significant difference between groups at equivalent times (ANOVA, Duncan's multiple range test; $p<0.05$ ).

EL, erythrocyte major axis; EW, erythrocyte minor axis; NL, nucleus major axis; NW, nucleus minor axis; ES, erythrocyte size; NS, nucleus size.

were evaluated under different water temperatures $\left(25^{\circ} \mathrm{C}\right.$, $28^{\circ} \mathrm{C}, 31^{\circ} \mathrm{C}$, and $34^{\circ} \mathrm{C}$ ) to investigate their use as an indicator of thermal stress in red spotted grouper.

In the present study, changes in erythrocytes and their nucleus structure were observed in E. akaara under elevated water temperature $\left(31^{\circ} \mathrm{C}\right.$ and $\left.34^{\circ} \mathrm{C}\right)$. In our previous study, we reported that thermal stress causes various types of erythrocytic cellular abnormalities (ECA) in E. akaara (Rahman et al., 2019). The erythrocytes of $25^{\circ} \mathrm{C}$ and $28^{\circ} \mathrm{C}$ were found in oval to elliptical shape, but turned into round shape when exposed to $31^{\circ} \mathrm{C}$ and $34^{\circ} \mathrm{C}$. These altered structure in erythrocytes and nucleus can induce anemic condition to the thermally stressed fishes. Similar abnormalities in erythrocyte and nuclei were reported in striped catfish, Pangasianodon hypophthalmus when treated with higher temperature $\left(36^{\circ} \mathrm{C}\right)$ for $7-28$ days (Shahjahan et al., 2018; Islam et al., 2019). The observed structural changes in erythrocyte and nuclei may be attributed to one or more of the following factors: (i) unequal distribution of hemoglobin (Mekkawy et al., 2011); (ii) necrosis of the red blood cells (Ateeq et al., 2002); (iii) interruption in lipid solubility to erythrocyte's membrane (Walia et al., 2013).

Fish erythrocytes and their nucleus have a wide range of shape and sizes among different species (Jagoe \& Welter, 1995). The changes in erythrocytes depend on the fish species, age, health and the environment where the fish live (Vazquez \& Guerrero, 2007; Zexia et al., 2007; Motlagh et al., 2012). Measurement of morphometric indices of erythrocytes and nucleus [major axis, minor axis, and size] under different water temperatures $\left(25^{\circ} \mathrm{C}\right.$, 
Table 2. Pearson correlation coefficient and the regression equation for the morphometric indices of erythrocytes and nucleus in red spotted grouper, Epinephelus akaara

\begin{tabular}{cc}
\hline \hline Paired samples & Correlation coefficient (r) \\
\hline EL (x) vs. EW (y) & $-0.740^{* *}$ \\
NL (x) vs. NW (y) & $-0.617^{* *}$ \\
EL (x) vs. NL (y) & $0.830^{* *}$ \\
EW (x) vs. NW (y) & $0.796^{* *}$ \\
EL (x) vs. NW (y) & $-0.814^{* *}$ \\
EW (x) vs. NL (y) & $-0.536^{* *}$ \\
\hline
\end{tabular}

See the regression plot (Fig. 2a-f) for each paired samples ${ }^{* *} p<0.01$

EL, erythrocyte major axis; EW, erythrocyte minor axis; $\mathrm{NL}$, nucleus major axis; NW, nucleus minor axis; ES, erythrocyte size; NS, nucleus size.

$28^{\circ} \mathrm{C}, 31^{\circ} \mathrm{C}$, and $34^{\circ} \mathrm{C}$ ) demonstrated that erythrocytes and their nucleus varied in size at higher temperature $\left(31^{\circ} \mathrm{C}\right.$ and $34^{\circ} \mathrm{C}$ ) which is the clear indication of stress. The observed decrease in major axis (EL, NL) and increase in minor axis (EW, NW) of erythrocytes and their nucleus might be because of changing the erythrocyte's shape from elongate to round which causes the reduction in major axis and enlargement in minor axis. The observed variation could also be explained by the following factors: (i) differing the dissolved oxygen levels in experimental groups; (ii) the maturation stage of the erythrocytes; (iii) the sample size of research. These findings are consistent with those of Rowan (2007), who reported that erythrocyte and nucleus morphometry of brown bullheads (Ameiurus nebulosus) were affected due to the pollution of river water by agricultural runoffs or industrial effluents. Similar results were also reported in Nile tilapia (Oreochromis niloticus niloticus) and African catfish (Clarias gariepinus) collected from contaminated sites of the river Nile (Osman et al., 2018). In this study, the strong relationships were observed among the morphometric indices of erythrocytes and their nucleus. Hardie \& Hebert (2003) reported that erythrocytes and nuclear sizes are significantly correlated in ray-finned fishes, cartilaginous fishes and all species combined.

In conclusion, the results of the present study reveal that elevated water temperature $\left(31^{\circ} \mathrm{C}\right.$ and $\left.34^{\circ} \mathrm{C}\right)$ beyond the optimal range $\left(24^{\circ} \mathrm{C}-28^{\circ} \mathrm{C}\right)$ affects the morphometric indices of erythrocytes and their nucleus, especially EL, EW, NL, and NW which can be considered as stress indicators (i.e., thermal stress) of red spotted grouper. This fine information may be helpful to monitor the health status of E. akaara and probably for other fish species.

\section{ORCID}

\author{
Md Mofizur Rahman \\ https://orcid.org/ 0000-0002-0013-3538
}

Hea Ja Baek

https://orcid.org/ 0000-0002-4578-5919

\section{CONFLICT OF INTEREST}

The authors declare no potential conflict of interest.

\section{ACKNOWLEDGEMENTS}

This research was supported by a grant (213008-05-3WT511) from the Korean Ministry of Agriculture, Food and Rural Affairs (MAFRA), the Korean Ministry of Oceans and Fisheries (MOF), the Korean Rural Development Administration (RDA), and the Korea Forest Service (KFS).

\section{AUTHOR CONTRIBUTIONS}

Conceptualization: Baek HJ.

Data curation: Rahman MM.

Formal analysis: Rahman MM.

Methodology: Rahman MM, Baek HJ. 

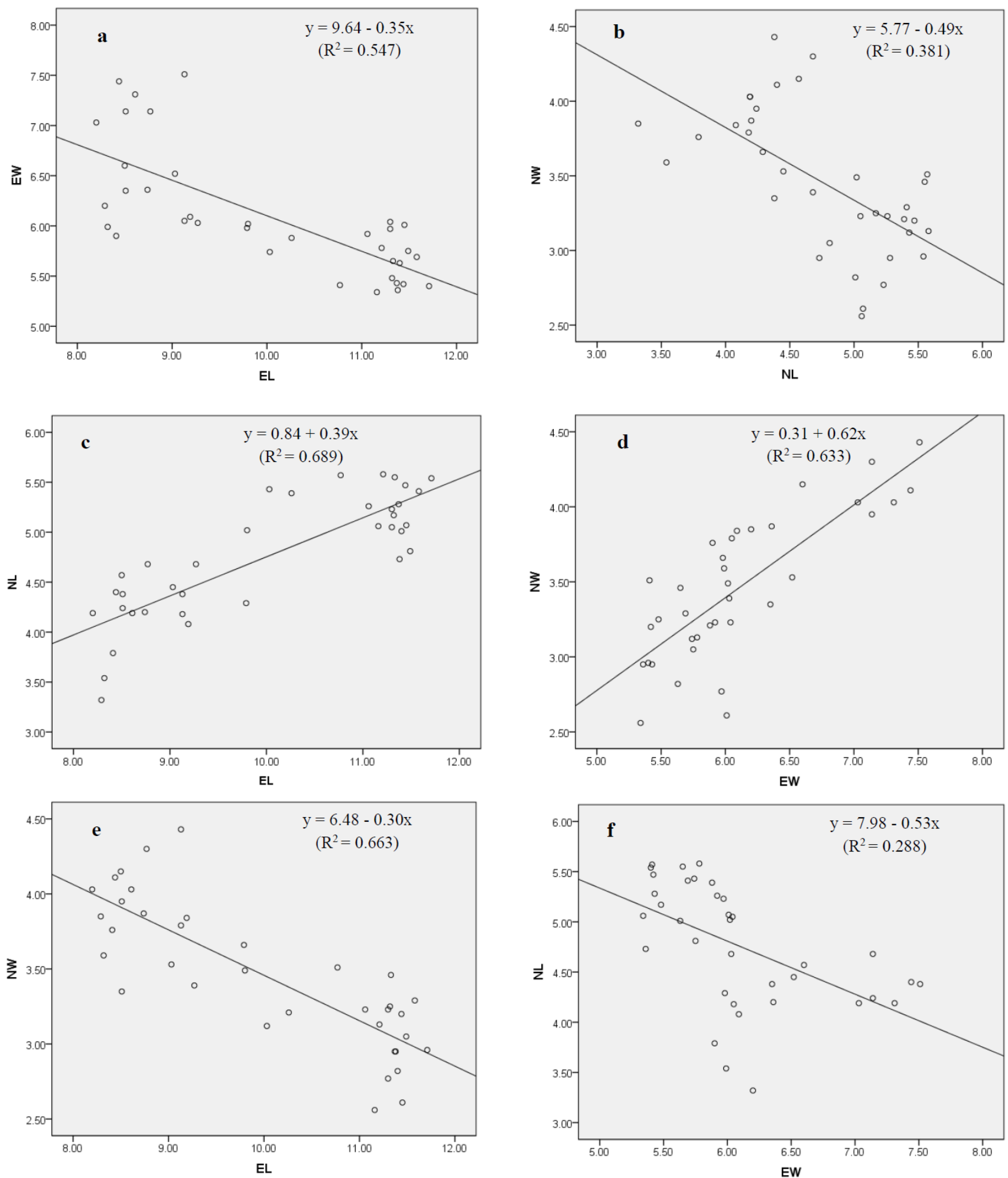

Fig. 2. Linear correlations among the morphometric indices of erythrocytes and their nucleus in red spotted grouper:

Epinephelus akaraa. (a) Erythrocyte major axis (EL) vs. Erythrocyte minor axis (EW); (b) Nucleus major axis (NL) vs. Nucleus minor axis (NW); (c) Erythrocyte major axis (EL) vs. Nucleus major axis (NL); (d) Erythrocyte minor axis (EW) vs. Nucleus minor axis (NW); (e) Erythrocyte major axis (EL) vs. Nucleus minor axis (NW); (f) Erythrocyte minor axis (EW) vs. Nucleus major axis (NL). 
Software: Rahman MM.

Validation: Rahman MM, Baek HJ.

Investigation: Rahman MM.

Writing - original draft: Rahman MM, Baek HJ.

Writing - review \& editing: Rahman MM, Baek HJ.

\section{ETHICS APPROVAL}

This article does not require IRB/IACUC approval because there are no human and animal participants.

\section{REFERENCES}

Ateeq B, Abulfarah M, Ali MN, Ahmad W (2002) Induction of micronuclei and erythrocyte alterations in the catfish Clarias batrachus by 2,4-dichlorophenoxyacetic acid and butachlor. Mutat Res 518:135-144.

Barcellos LJG, Kreutz LC, de Souza C, Rodriguez LB, Fioreze I, Quevedo RM, Cericato L, Soso AB, Fagundes M, Conrad J, Lacerda LA, Terra S (2004) Hematological changes in Jundia (Rhamdia quelen) after acute and chronic stress caused by usual aquacultural management, with emphasis on immunosuppressive effects. Aquaculture 237:229-236.

Borges A, Scotti LV, Siqueira DR, Zanini R, Do Amaral F, Jurinitz DF, Wassermann GF (2007) Changes in hematological and serum biochemical values in Jundia Rhamdia quelen due to sub-lethal toxicity of cypermethrin. Chemosphere 69:920-926.

Cho HC, Kim JE, Kim HB, Baek HJ (2015) Effects of water temperature change on the hematological responses and plasma cortisol levels in growing of red spotted grouper, Epinephelus akaara. Dev Reprod 19:19-24.

De M, Ghaffar MA, Noor NM, Cob ZC, Bakar Y, Das SK (2019) Effects of water temperature and diet on blood parameters and stress levels in hybrid grouper (Epinephelusfuscoguttatus $\bigcirc \times$ E. lanceolatus $\bigcirc$ ) juveniles. Aquac Rep 15:100219.
Fang J, Chen K, Cui HM, Peng X, Li T, Zuo ZC (2014) Morphological and cytochemical studies of peripheral blood cells of Schizothorax prenanti. Anat Histol Embryol 43:386-394.

Fazio F, Filiciotto F, Marafioti S, Di Stefano V, Assenza A, Placenti F, Buscaino G, Piccione G, Mazzola S (2012) Automatic analysis to assess haematological parameters in farmed gilthead sea bream (Sparus aurata Linnaeus, 1758). Mar Freshw Behav Physiol 45:63-73.

Fu KK, Fu C, Qin YL, Bai Y, Fu SJ (2018) The thermal acclimation rate varied among physiological functions and temperature regimes in a common cyprinid fish. Aquaculture 495:393-401.

Hardie DC, Hebert PDN (2003) The nucleotypic effects of cellular DNA content in cartilaginous and ray-finned fishes. Genome 46:683-706.

Howerton R (2001) Best management practices for Hawaiian aquaculture. Center for Tropical and Subtropical Aquaculture, Waimanalo, Publication No. 148.

Islam MA, Uddin MH, Uddin MJ, Shahjahan M (2019) Temperature changes influenced the growth performance and physiological functions of Thai pangas Pangasianodon hypophthalmus. Aquac Rep 13:100179.

Jagoe CH, Welter DA (1995) Quantitative comparisons of the morphology and ultrastructure of erythrocyte nuclei from seven freshwater fish species. Can J Zool 73:19511959.

Lee JW, Baek HJ (2018) Determination of optimal temperature(s) in juvenile red-spotted grouper Epinephelus akaara (Temminck \& Schlegel) based on growth performance and stress responses. Aquac Res 49:3228-3233.

Lowe-Jinde L, Niimi AJ (1983) Influence of sampling on the interpretation of haematologicalmeasurements of rainbow trout, Salmo gairdneri. Can J Zool 61:396402.

Mekkawy IA, Mahmoud UM, Sayed AEH (2011) Effects of 4-nonylphenol on blood cells of the African catfish 
Clarias gariepinus (Burchell, 1822). Tissue Cell 43:223-229.

Metin K, Koca YB, Kiral FK, Koca S, Turkozan O (2008) Blood cell morphology and plasma biochemistry of captive Mauremys caspica (Gmelin, 1774) and Mauremys rivulata (Valenciennes, 1833). Acta Vet Brno 77:163174.

Morris AV, Roberts CM, Hawkins JP (2000) The threatened status of groupers (Epinephelinae). Biodivers Conserv 9:919-942.

Motlagh SP, Zarejabad AM, Nasrabadi RG, Ahmadifar E, Molaee M (2012) Haematology, morphology and blood cells characteristics of male and female Siamese fighting fish (Bettasplendens). Comp Clin Pathol $21: 15-21$.

Najiah M, Nadirah M, Marina H, Lee SW, Nazaha WH (2008) Quantitative comparisons of erythrocyte morphology in healthy freshwater fish species from Malaysia. Res J Fish Hydrobiol 3:32-35.

Osman AGM, AbouelFadl KY, Abd El Reheem AEM, Mahmoud UM, Kloas W, Moustafa MA (2018) Blood biomarkers in Nile tilapia Oreochromis niloticus niloticus and African catfish Clarias gariepinus to evaluate water quality of the river Nile. J Fish Sci Com 12:1-15.

Rahman MM, Kim HB, Baek HJ (2019) Changes in blood cell morphology and number of red spotted grouper, Epinephelus akaara in response to thermal stress. Dev Reprod 23:139-148.
Rowan MW (2007) Use of blood parameters as biomarkers in brown bullheads (Ameiurus nebulosus) from Lake Erie tributaries and Cape Cod ponds. Doctoral dissertation, The Ohio State University.

Ruas CBG, Carvalho CD, de Araujo, HSS, Espindola ELG, Fernandes MN (2008) Oxidative stress biomarkers of exposure in the blood of cichlid species from a metal-contaminated river. Ecotox Environ Safe 71:8693.

Sadovy Y, Cornish AS (2000) Reef fishes of Hong Kong. Hong Kong University Press, Hong Kong.

Shahjahan M, Uddin MH, Bain V, Haque MM (2018) Increased water temperature altered hemato-biochemical parameters and structure of peripheral erythrocytes in striped catfish Pangasianodon hypophthalmus. Fish Physiol Biochem 44:1309-1318.

Vazquez GR, Guerrero GA (2007) Characterization of blood cells and hematological parameters in Cichlasoma dimerus (Teleostei, Perciformes). Tissue Cell 39:151160.

Walia GK, Handa D, Kaur H, Kalotra R (2013) Erythrocyte abnormalities in a freshwater fish, Labeo rohita exposed to tannery industry effluent. Int J Pharm Biol Sci 3:287-295.

Zexia G, Weimin W, Yi Y, Abbas K, Dapeng L, Guiwei Z, Diana JS (2007) Morphological studies of peripheral blood cells of the Chinese sturgeon, Acipenser sinensis. Fish Physiol Biochem 33:213-222. 